\title{
Polish Catholic Bishops, Nationalism and Liberal Democracy
}

\author{
Madalena Meyer Resende ${ }^{1, *(\mathbb{D})}$ and Anja Hennig ${ }^{2}$ \\ 1 Instituto Português de Relações Internacionais, NOVA University of Lisbon, 1069-061 Lisboa, Portugal \\ 2 Faculty of Social and Cultural Studies, Europa Universitaet Viadrina, D-15230 Frankfurt (Oder), Germany; \\ ahennig@europa-uni.de \\ * Correspondence: madalena.resende@fcsh.unl.pt
}

Citation: Meyer Resende, Madalena, and Anja Hennig. 2021. Polish

Catholic Bishops, Nationalism and

Liberal Democracy. Religions 12: 94.

https://doi.org/10.3390/rel12020094

Received: 26 October 2020

Accepted: 15 January 2021

Published: 30 January 2021

Publisher's Note: MDPI stays neutral with regard to jurisdictional claims in published maps and institutional affiliations.

Copyright: (c) 2021 by the authors. Licensee MDPI, Basel, Switzerland. This article is an open access article distributed under the terms and conditions of the Creative Commons Attribution (CC BY) license (https:// creativecommons.org/licenses/by/ $4.0 /)$.

\begin{abstract}
The alliance of the Polish Catholic Church with the Law and Justice (PiS) government has been widely reported and resulted in significant benefits for the Church. However, beginning in mid-2016, the top church leadership, including the Episcopal Conference, has distanced itself from the government and condemned its use of National Catholicism as legitimation rhetoric for the government's malpractices in the fields of human rights and democracy. How to account for this behavior? The article proposes two explanations. The first is that the alliance of the PiS with the nationalist wing of the Church, while legitimating its illiberal refugee policy and attacks on democratic institutions of the government, further radicalized the National Catholic faction of the Polish Church and motivated a reaction of the liberal and mainstream conservative prelates. The leaders of the Episcopate, facing an empowered and radical National Catholic faction, pushed back with a doctrinal clarification of Catholic orthodoxy. The second explanatory path considers the transnational influence of Catholicism, in particular of Pope Francis' intervention in favor of refugee rights as prompting the mainstream bishops to reestablish the Catholic orthodoxy. The article starts by tracing the opposition of the Bishops Conference and liberal prelates to the government's refugee and autocratizing policies. Second, it describes the dynamics of the Church's internal polarization during the PiS government. Third, it traces and contextualizes the intervention of Pope Francis during the asylum political crisis (2015-2016). Fourth, it portrays their respective impact: while the Pope's intervention triggered the bishops' response, the deepening rifts between liberal and nationalist factions of Polish Catholicism are the ground cause for the reaction.
\end{abstract}

Keywords: political Catholicism; Polish politics; nationalism

\section{Introduction}

The Catholic support for nationalism and the Law and Justice (PiS) party in Poland is well known, as is clear the unity between the two in moral matters, such as abortion and gay rights (Deutschlandfunk 2017a). The PiS government, as it took office in 2015, excluded state support for in vitro fertilization and initiated the adoption by Parliament of a law banning abortion. This eventually brought about the "Black Protest of the Women", one of the largest protest movements in the country. In matters of gender, women's rights and LGBTI, the Church and the nationalist government are also clearly aligned (see Żuk and Żuk 2020). Why, then, have the liberal and mainstream bishops, from mid-2016, shifted to an attitude of distance and even criticism of the government? This article aims to understand the multifaceted relationship between the Polish Episcopate and clergy, both as a collective - the Polish Bishops Conference-and as individual bishops and priests, and the PiS party and government. Notwithstanding the phenomena of sectarian nationalism being widely reported as a trend across the world, few systematic studies present and explain how the churches are impacted by alliances with nationalist and anti-democratic parties. Moreover, as many of these parties and actors adopt illiberal and anti-democratic practices, the churches-especially Christian ones-see their religious symbols used to legitimize violations of human rights and autocratizing practices. 
At stake are two conceptions of liberal democracy. On one hand, that of Catholic political theology, which maintains that issues such as abortion are a violation of human rights and should therefore be insulated from majoritarian decision-making. In opposition, liberals and secularists, who consider abortion and other moral issues as part of human rights, claim that liberal democratic regimes should protect these freedoms and include these as part of the liberal democratic values. The increasing tensions between the conservative and the liberalizing positions on moral issues are one of the factors driving the rise of the extreme right in the last decades (Minkenberg 2018). The radical nationalist right has adopted religious tropes not only in Poland but also in Italy, Spain and Hungary. Around the world, alliances between nationalists and their countries' majority religions helped these forces to reach office in several major powers, including, among others, Jareendra Modi in India, Donald Trump in the US and Jair Bolsonaro in Brazil.

The article considers two pathways of explanation. The first looks at the Polish Church's internal dynamics, namely the effects of the radicalization of the National Catholic faction and the reputational loss this caused to the Church. The second explanatory path explores the impact of transnational Catholicism on the behavior of the Polish Episcopate and clergy. It focuses, in particular, on the Pope's visit to Poland in July 2016 and his attempt to restore the orthodox catholic political theology.

The analysis of the behavior of the Polish clergy in the first term of the PiS government helps to explain the quick shift in the attitude of the church hierarchy towards the government. The conclusion states that the change of behavior of the Polish Episcopate results, first, from the negative effects that the alliance had on the radicalization of the National Catholic faction. Facing an empowered National Catholicism, the Episcopate resolved that the government's embrace of the Church was costly and inconvenient. Second, we conclude that the impact of the Vatican intervention was limited. Although the visit of Pope Francis triggered the Episcopate's response, the Polish Bishops position was chiefly sustained by internal polarization and only secondarily by doctrinal imposition from Rome.

Albeit focusing on the clerical actors within the Catholic Church, we acknowledge that the Catholic laity-and lay organizations-are important elements of this process. On one hand, lay organizations had a crucial role in the liberalization of the Church and continue to be important civil society and political actors. Moreover, the laity, which is also an important part of the Catholic electorate, is as divided, and along similar lines, as the clergy (Turska-Kawa and Wojtasik 2017). On the other hand, the nationalist and conservative lay groups are also relevant elements in the Church's debates on nationalism, democracy and human rights. However, we chose to focus on the inter-ecclesiastic conflicts (both among the Polish clergy and between the national and the transnational (Vatican) levels. We will, however, discuss the effects of the erosion of church authority due to the alliance with the PiS among the laity, especially that of liberal orientation.

We justify the focus on the clerical aspect of the Catholic Church-as opposed to the full, living Catholic Church, including the laity-by the weight and size of the secular clergy and bishops in Poland. Unlike in other national churches, like in Spain, where strong lay movements and regular clergy hold sway over the public intervention of the Church, in Poland, the secular prelates have traditionally held a great amount of control over the public and political actions of the Church. Therefore, although keeping in mind the whole of the Church, we bracket the laity to focus on the impact of the party-church alliance on the internal dynamics and conflicts among the clergy.

The Vatican Council II (1962-1965) doctrine on human rights and liberal democracy is a central aspect of the Church's political theology and continued to be developed and applied in the decades following the Council (Perreau-Saussine 2012). In terms of refugee rights - while acknowledging the right of nations to regulate migration across their borders - the Church considers that asylum and refugee rights are human rights. Regardless of the asylum seekers' citizenship, religion, visa status or mode of arrival, states are bound to accept them (Pope Benedict XVI 2010, N 16; Pontifical C Pontifical Council Cor et Unum 2013, N 60-1; Pontifical Council for Justice and Peace 2005, N 108). In terms 
of democracy, the doctrine of the fundamental compatibility between the Church doctrine and liberal democracy was spelled in the Declaration on Religious Freedom (1965), Dignitatis Humanae and in the Pastoral Constitution on the Church in the Modern World (1965), Gaudium et Spes.

Since the Council, however, there have been increasing tensions between the positions of the Church on moral issues-including arguments that these should be insulated from majoritarianism - and many secular and even some Catholic liberals who claim that these are key human rights issues (see Christians 2006). The church argument for insulating certain moral values from majoritarianism, and the lengths to which it is prepared to intervene in the political arena to ensure that these religious rules are translated into civil law, are arenas of great tension within the church liberal and conservative factions and between the Church and liberal secular forces. Therefore, although the refusal of abortion is accepted as a conservative but not illiberal position by most Catholics, the question of the church intervention to impose it on civil legislation is more problematic (Christians 2006). As liberal democracies face pressures for increasing areas of cultural and social life to embrace novel values and forms, the more conservative Central and Eastern European populations face further tensions between their moral views and the perceived cultural colonization from the liberal West (Pew Research Center 2017a, 2017b). In Poland, these tensions are particularly acute, with conflicts over moral policies being central political and social arenas in the dispute for political power, and the debates on migration and refugee policies also revolving around the defense of traditional Christian values.

In the reconciliation between the Church's resistance to moral liberalization and the aggiornamento with liberal democracy, Pope John Paul II had a crucial role. Archbishop Wojtyla-later Pope John Paul II-was both an ardent promoter of the Universalist values of human rights and liberal democracy and a convinced advocate of the Church's role in promoting conservative morality, including church intervention in the political arena to prevent the liberalization of personal civil legislation. John Paul II embodied the tensions of late 20th-century political Catholicism but was also the author of a formula that, for more than three decades, allowed to reconcile the conservatives and liberal Catholic factions in the aftermath of the Second Vatican Council. In Poland, John Paul II's pontificate was a determinant factor in the national Church's alignment with liberal democracy while deepening the moral conservatism in the country (Williams 1981; Gregg 2002; Weigel 2010). In line with his universalist convictions, the Pope was also a constraining force on the National Catholic faction of the Church, with heavy influence not only on the nomination of Bishops but also in political questions, such the countries' accession to European integration or the support to National Catholic parties (John Paul II 1999).

While the Catholic Church's contribution to democratization during the Third Wave of democratization, also called the Catholic Wave, is well-documented (Philpott 2004; Anderson 2007; Stepan 2000; Linz 1991), the conduct of the Catholic Church during the authoritarian turn that recently swept the world is less explored. The understanding of how heightened religious polarization affects the Church's ability to respond to these processes is also lacking. This is most relevant as a number of political actors and parties responsible for the degradation of democracy have sought legitimization through reference to Christianity as a marker of identity. We also provide insights about why and how National Catholicism grew in Poland, which can be helpful to understand the sources of the simultaneous rise in support for religious nationalism in Europe and beyond.

This article proceeds as follows. The second section outlines the hypothesis, presents the method, and contextualizes the choice of the Polish case. The third section outlines the outcome, i.e., the Catholic Church's behavior during the first term of the PiS government, focusing on policies towards refugees and democratic institutions (2015-2019). The fourth section traces the development of the internal and external factors, i.e., the deepening inner-church polarization and the impact of Pope Francis's intervention. In the fifth and final section, we identify the impact of the factors on the Episcopate behavior towards the PiS government. 


\section{Explanatory Pathways, Methodology, and Choice of Case}

From 2010, the PiS and the national Catholic clergy formed a tacit alliance, which helped the party to reach victory in the 2015 parliamentary and presidential elections. By mid-2016, however, the Episcopate started to show distance from the government by criticizing the PiS' refugee policy. In 2017, the Episcopate and the majority of mainstream conservative Bishops, leaders of the Church, raised the tone in criticism of the government's anti-democratic policies, incentivizing President Andrzej Duda to veto anti-democratic laws and elaborating on the theological basis of the church alignment with liberal democracy.

The first explanatory path for the distancing is the internal dynamics of the Polish Church, namely the polarization of the Church and the erosion of the advantages of its alliance with the government. We examine how the radicalization and ideological convergence between the PiS, and the National Catholics made the Bishops re-evaluate the alliance with the PiS. Here we follow the path launched by Grzymala-Busse, in Nations Under God (Grzymala-Busse 2015), which posits that church alliance with political parties usually results in clerical loss of moral authority. In the attempt to recover it, the church authorities will try to disentangle the Church from the embrace of the party. The article also borrows from Hennig's analysis of religious polarization in the context of alliances between religious institutions and illiberal actors (see Hennig and Weiberg-Salzmann 2020). Grzymala-Busse's insights confirm that the negative effects of church-party alliances on the churches' moral authority are valid even in cases where, like in Poland, the Catholic Church largely resisted the trends of secularization in the second part of the 20th-century. The Polish case is thus a hard case that confirms Grzymala-Busse's thesis and applies it to a context of political autocratization.

The second path follows the insight laid by scholars arguing that the Vatican intervention, often to reinstate doctrinal orthodoxy, has a strong impact on the national Episcopate's decisions. Here we speak about Pope Francis' attempt to reestablish human rights and the tradition of supporting liberal democracy, consolidated by the vigorous interventions of Pope John Paul II in democratization processes (Philpott 2004). The pro-democratic theology of the Church is both pushed by the Vatican and implemented by the highest authorities of the national Episcopate. This hypothesis also borrows from Künkler and Leininger's assertion regarding the centrality of pro-democratic theology for religious institutions' actions on democracy and autocratization (Künkler and Leininger 2021). The analysis of the Polish case reveals how the relation of the Pontifex with national hierarchies is a two-way affair, with the authority of the Pope being often diminished or defied by tensions between the two levels.

The article traces the actions of the Polish Church, covering the interventions of the Vatican and the Pope, the top leadership of the Church, the Episcopate as a collective entity, individual Bishops, and, finally, relevant Catholic ecclesiastic groups and prominent laypeople. The analysis identifies turning points in the actions of the Episcopate towards the government, as well as tracing the polarization of church factions. We base the empirical analysis on media reports, official church documents, public pronouncements and sermons, especially those that hinge on nationalism, refugees, and democracy.

Poland is the most evident case in Europe of an alliance between the government and a politically powerful church, where both the liberal and the nationalist camp have strong traditions. Moreover, the PiS government's disrespect for core human rights (refugees) and the institutions of liberal democracy challenged the Polish Church to respond. The Polish case is thus broadly relevant to understand the response of the Catholic Church to the nationalists' borrowing of Christian tropes.

\section{The Distancing of the Episcopate to the PiS Government during the Asylum and Democracy Crisis}

In this section, we introduce the Episcopate's distancing from the PiS government by describing the break. The explanation and context of this process will be presented in Section 4. Despite the advantages reaped by the Church after supporting the PiS in the 
2015 elections (Nosowski 2016), by mid-2016, the Episcopate and the highest authorities in the Polish Church shifted their position towards the government. We trace the Episcopate actions and rhetoric during the refugee (2015-2016) and democratic crisis (2016). The bishops condemned the National Catholic doctrine as un-Christian, censuring both its nationalist and its anti-democratic political theology. Archbishop Gądecki, the head of the Polish Episcopate, used his authority to reaffirm the principles of the church creed.

\subsection{Asylum Political Crisis}

The 2015 presidential and parliamentary elections took place at the highest point of the refugee intake from the Middle East to Europe. During the parliamentary electoral campaign, the PiS refused the relocation of 1000 immigrants, as negotiated by the Polish government and the European Commission.

The Polish Episcopate first expressed opposition to the PiS government's refusal to accept refugees in the summer of 2016 and specified its disapproval of the use of Christian arguments to legitimize the refusal of Muslim applicants (Luxmoore 2017). Several bishops, including the head of the Episcopal Conference, affirmed the duty of hospitality towards refugees (Catholic 2017).

In April 2017, the Episcopal Conference elaborated a doctrinal document against the radicalization of National Catholicism. The doctrinal statement "The Christian form of patriotism" (Polish Bishops Conference 2017; Deutschlandfunk 2017b) tried to build a distinction between patriotism, as an extension of the love of one's family, from nationalism, an ideology built on hatred for the other nations, in particular those of different religions. The document deemed that patriotism is compatible with Christian ethics, while nationalism goes squarely against the church teaching of "love thy neighbor". The Episcopate praised the civic inclusiveness of the patriotic identification with the Polish nation, as well as the friendly relation with other nations, and condemned the aggressive and xenophobic Catholic nationalism mobilized by the PiS while denouncing the use of Catholic symbols and rhetorical resources to legitimize the inhuman refugee policy of the government (Polish Bishops Conference 2017). The document "Christian patriotism" also contradicts the nationalist claim of an ascriptive identity of a pre-political nation, a notion that undermines the authority of the state over those under its jurisdiction.

In November 2017, the Episcopal Conference asserted its opposition to unchristian nationalism by refusing to celebrate a mass for the rally on Polish Independence Day (Evangelisch 2017). The President of the Episcopal Conference also showed disapproval of the government's tolerance for the radical nationalist movements organizing the eventsthe ONR and the MW. The Episcopate was particularly critical of the radical use of Catholicism and an Islamophobic agenda as a marker of Polish nationalism-a practice that was encouraged by both the PiS government and the nationalist part of the clergy (Gadek 2017).

In addition to its opposition to the government anti-refugee policy, the Episcopal Conference feted, in January 2018, the Migrants Day ${ }^{1}$ followed, two days later, by the celebration of the Day of Judaism. In these celebrations, Archbishop Stanislaw Gadecki, the Chairman of the Polish Bishops Conference and one of the most respected prelates in the country, refuted nationalism as a dangerous ideology and contrasted it with a benevolent Christian patriotism (Tygodnik Powszechny 2018b). Another of the top prelates, Archbishop Nycz, publicly pleaded with the government to accept refugees and encouraged local parishes to support the initiative of holding "masses for refugees and asylum-seekers." (Crux 2018). At a press conference for World Migrant day, Bishop Krzystof Zadarko presented a document offering church support to migrants and refugees (Vatican News 2018). Both initiatives were widely covered by the media.

1 See https:/ / episkopat.pl/14-stycznia-swiatowy-dzien-migranta-i-uchodzcy/ś (accessed on 20 March 2020). 


\subsection{Democracy Crisis}

The government attack on democratic institutions-starting with the assault on the rule of law and the free media-intensified in June 2017 with the adoption of the new Law on the Supreme Court. The legislation foresaw the compulsive early retirement of judges, opening the way for their replacement by government appointees. This move triggered a wave of widespread and systematic social protests and resulted in strong criticism by a number of international organizations, including the Venice Commission of the Council of Europe and the European Commission.

From June 2017, the Catholic ecclesiastic elite, led by the Arch. Gadecki and the Archbishop of Gniezno and Primate of Poland, Wojciech Polak issued public warnings against the government's dismantling of democratic institutions (Deutsche Welle 2017; Deutschlandfunk 2017d). In August 2017, at a mass attended by Prime Minister Beata Szydlo and President Andrzej Duda, Primate Polak urged the government to respect the constitution (Catholic 2017). In addition, amidst strong public opposition to the government's reforms of the judicial branch, both prelates stated that "authentic democracy is only possible in a state that respects the rule of law" and incited President Duda to veto two of the central aspects of the reform, a request to which the President abided (Deutschlandfunk 2017d).

President Duda's announcement of a referendum to change the Polish democratic constitution (3 May 2018) led the Bishops to reaffirm the Catholic alignment with liberal constitutionalism. Raising the tone against the government, the bishops accused the government of violating the 1997 Constitution. Bishop Zadarko declared that "politicians that hold the most beautifully published copy of the Constitution, while having no intention to respect it, are an offense to God" (Redakcja Więz 2018). A few days later, on 13 May 2018, at a mass celebrating Saint Stanislaw, Patron Saint of a Moral Order, Archbishop Stanislaw Gadecki reiterated the terms of the post-Vatican II pro-democratic political theology with a long and learned sermon. Using the motto of the occasion-the festivity of Saint Stanislaw's resistance to the corruption of power by the Polish King-Gadecki denounced the PiS judicial reform as an attack on the rule of law and separation of power, as well as refuting the validity of National Catholic justifications for such actions (Gacdecki 2018). ${ }^{2}$

In the sermon, Gadecki confronted the fundamental conflict dividing Polish Catholicism since 1989. At stake was the discord between liberals, who defined the political community through a liberal interpretation of the nature of the pre-political contract, and those considering such pre-political contract as based on an ascribed National Catholic identity. Arch. Gądecki's sermon was a re-affirmation of the liberal nature of the prepolitical foundation of democracy (Gaadecki 2018). Citing the Catholic political theorist E.H. Böckenforde, the prelate asserted that, although affirming the need for a core of values insulated from majoritarian decisions, the Church nevertheless accepts the pluralist nature of the political community and lauds the principles of democratic rule, above all the rule of law and division of powers (Gadecki 2018). The liberal political theology affirmed by Gadecki rejects the nationalist and anti-democratic theology inherent in the PiS government and its supporters within the Church. The conservative liberals at the helm of the Polish Church nevertheless declared the centrality of moral (and religious) values as foundations of democracy and asserted that these values should be insulated from majoritarianism (see Stein 2018; Manent 2018).

The Archbishop's sermon puts into relief the theological differences between liberals and National Catholics. On the basis of these different assumptions on the political community, liberals and National Catholics hold different stances on liberal democracy. National Catholics define the political community as that of Catholic Poles. Such a homogenous political community ultimately dispenses the institutional mechanisms of representation to distill the public interest since the party representing the community of Catholic Poles le-

2 The Polish Bishops Conference issued a follow-up document reinforcing the message that the church is pro-democracy (Polish Bishops Conference 2018). 
gitimately translates the interests of the nation into policy. National Catholics also dispense the mechanisms of balance of power, used to keep the executive in check.

Tension arose again between the church hierarchy and the government when, in July 2018, the Parliament approved a new electoral law for the European Parliament elections. With the intention of eliminating many of the smaller competing parties, it imposed a 16 percent threshold on parties. Upon the suggestion of Primate Polak and Archbishop Gąecki, President Duda vetoed the law.

In November 2018, as Poland celebrated a century of independence, the Episcopate distanced itself from the celebrations-which joined extreme nationalist organizations and the government in a massive rally that marched through the main streets of Warsaw. The rally was notorious for the demonstrations of radical nationalism and the appropriation of Christian symbols (Kadras 2019). Unlike the PiS government, which allowed the official celebrations to be joined with those organized by radical nationalist groups (Gazeta Wyborcza 2019), the bishops refused to allow an open-air mass in front of the Parliament, as had been requested by the organizers (OKO Press 2018).

\section{Explanatory Paths}

\subsection{Internal Polarization in the Polish Catholic Church Since 1989}

During the communist period (1947-1989), and particularly since the emergence of the Solidarity Trade Union in 1980, the Polish Church was unified on the side of Solidarity in the fight against a totalitarian and atheistic state. Since the transition to democracy, however, the Church responded in different ways to the secularization of society, and this led to the deepening of ideological antagonism among the Church's three main factions. During the three decades after 1989, the Church's internal cohesion declined, and a process of ideological differentiation took root both in the clergy and the faithful, and this differentiation ran along an axis of nationalist/conservative vs. a more liberal/secular Catholicism (Narkowicz 2018; Gowin 1999; Turska-Kawa and Wojtasik 2017). Although most of the processes described in this article involved an increasingly complicated and evolving relationship between faithful Catholics and the clergy, as well as secular friends and opponents of religion, we will focus here on the clergy's positioning.

The first group of clerics in the Polish Church consists of a minority of liberal priests and bishops that follow the pro-democracy orthodoxy of the Vatican Council II and argue for the Church to focus on its religious role (emphasis on belief) and take distance towards the political arena (Grabowska 2017). The second faction comprises the majority of centrist conservative and national-conservative bishops in the Polish Bishops Conference. The third group, encompassing the National Catholic bishops and priests, responded to post1989 secularization by pledging the establishment of Catholicism as a state religion and attempting to institutionalize the creed of the fusion between Catholicism and the Polish nation. This group focuses on the preservation of "belonging rather than believing", and this attitude underlies National Catholics' aim to maintain strong links with the political arena (Grabowska 2017). In the Polish Church, nationalists and liberals' main disagreement hinge on how the Church should relate with the political realm, ${ }^{3}$ with the three groups espousing different political theologies.

\subsubsection{Liberal Catholics}

The liberal faction stands in the tradition of liberal-intellectual Catholics that opposed communism. This resulted in a strong militancy for liberal democracy and criticism of the blurring of the lines of separation between Church and state. Liberal Catholics are rooted in respect for human rights, in particular religious freedom and liberal democracy. Polish liberal Catholicism emerged during communism, especially after 1956, with prelates such as Józef Tischner and Karol Wojtyla (future Pope John Paul II) as leaders of the Catholic

3 Jaroslaw Gowin identified and elaborated five groups within the Polish Catholic church (Gowin 1999): liberal Catholicism of protest, open Catholicism, Catholicism of Continuity, closed Catholicism and integral Catholicism. 
intelligentsia (Narkowicz 2018, p. 362). The Club of Catholic Intelligentsia (KIK), founded in 1956 in Warsaw, became the central network both during communist times, as well as during and after the transition. Following the values of the Vatican Council II, this group engaged with the worker's movement that emerged in the 1970s. Most liberal Catholic publications are associated with the KIK, such as the weekly Tygodnik Powszechny and the monthlies Więż and ZNAK (Garbowski 2014, p. 203).

The political role of liberals_-promoted by Pope John Paul II-during the Solidarity crisis (1980-1981) and later in the transition to democracy (1988-1990)-gave these prelates a strong public profile during the 1980s. However, after the breakup of the Solidarity movement in 1989/1990, the liberal group reacted to the secularization of the country by arguing for a retreat of the Church to a stricter religious role. This meant adopting an attitude of reserve towards intervention in the political arena and shunning any alliances with political parties. In 1993, and after the semi-formal support of the Church to National Catholic political forces, Pope John Paul II issued a prohibition of alliance with political parties.

These prelates were also instrumental in the negotiation of the 1997 Polish Constitution, serving as a counterweight to the demands of National Catholic bishops for the establishment of the Catholic Church in the new constitution. In their fundamental acceptance of a regime of separation-but cooperation-between Church and state, these prelates became the privileged interlocutors to the socialist government in the negotiations for the drafting of the 1997 Constitution (1994-1997), and instrumental in forging a settlement between secularists and National Catholics (Meyer Resende 2018). The ethos of this group is based on the maintenance of the political independence of the Church and the defense of liberal democracy. For liberals, defending these values is one of the few legitimate grounds for church intervention in the political arena (Garbowski 2014).

It is thus of little surprise that liberal Catholics opposed the alliance of the Church with the PiS, and that, from 2016, their condemnation became increasingly vocal and public. Adam Boniecki, the former editor-in-chief of the liberal Catholic weekly "Tygodnik Powszechny", denounced the alliance of the Church with the PiS. "The Church should stand above the political parties. It is lethal for the Church to ally with a party. Anyone who believes that we are becoming a Catholic country is wrong. It is a temptation to use worldly power to quasi-implement Christianity". Although liberal bishops and prelates are a minority, there are several outspoken voices among them. Other relevant liberal voices, such as the Dominican priest Ludwik Wiśniewski, raised their tone to condemn the "shameful appropriation of the Church by the PiS" (Tygodnik Powszechny 2018a). Other relevant voices were the ex-Jesuit priest Stanislaw Obirek (who left the Church several years ago), as well as the head of the Warsaw KIK section, Ignacy Dudkiewicz.

\subsubsection{The Conservative Center}

The bishops of the conservative milieu range from the morally conservative Archbishop Stanislaw Gadecki, head of the Polish Bishops Conference, to more moderate members (PAP 2014), such as liberal-minded bishop Tadeusz Pieronek (1933-2018). Many of these prelates, such as Primate Emeritus of Poland, Archbishop Henryk Muszynski or Archbishop of Krakow Franciszek Macharski, were promoted by Pope John Paul II. While favoring moral conservatism, these bishops hold firm on their defense of democratic principles and human rights. The mainstream bishops did not immediately condemn the alliance of the PiS with the Church (Evangelisch 2017).

\subsubsection{National Catholics}

As the only national institution surviving the partitions (1783-1918), the Polish Catholic Church assumed a central role in the Polish nation-building process. Catholicism, as a basis for the Polish identity, was an integral part of 19th-century nationalism. National Catholicism proclaims an ascribed identity based on an exclusivist Catholic Polishness. In the late 19th-century, the Endecja movement of Roman Dmowski politicized this associa- 
tion in a process that involved important tensions with traditional National Catholicism (Walicki 1994, 2000). During communist rule (1947-1989), the Church, suffering alongside the nation, re-gained the status of a national institution resisting the foreign and totalitarian rule from Moscow. After Stalinism (1947-1956), Cardinal Wyszynski-the leader of the only legal civil society organization in the country-orchestrated the mobilization of resistance to communism, with National Catholicism as the underlying legitimation rhetoric (Meyer Resende 2014). In the 1980s, the Solidarity movement brought together workers, intellectuals and the Catholic Church in an anti-totalitarian alliance that eventually created a synthesis of Liberal Democratic and National Catholic values, the "Solidarity ethos". Clerics such as Father Józef Tischner and John Paul II were crucial in this ideological elaboration (Acherson 1981, p. 267).

During the transition to democracy in 1988-1990, the dispute over the construction of a cross at the Carmelite Monastery bordering the Auschwitz camp pointed to the reawakening of National Catholicism as a force in the Polish Church (Zubrzycki 2006). The early nineties saw the dismantling of the unity between Catholicism and the political community that had been achieved during the Solidarity movement.

The National Catholic faction maintained links with political parties and social movements emerging after 1989, starting with the small but influential Christian-National Union (ZChN). After the demise of the ZChN in 2001, the League of Polish Families (LPR) replaced it as the representative of the Church in the political spectrum. The National Catholic wing also kept ties to nationalist social movements, such as the LPR's youth organization, the Młodzież Wszczech Polska (All Polish Youth), the far-right Obóz Narodowo-Radikalny (ONR, National-Radical Camp), the Ruch Narodowy (National Movement), the Polska Liga Obrony (Polish Defense League) and, finally, the Movement for the Reconstruction of Poland (Pankowski 2018). The relation of the Church with the nationalist right, albeit not amounting to an alliance before 2015, goes back to the democratic transition (Źuk and Zuk 2019).

The National Catholic faction also saw the emergence, in the early 1990s, of a strong social and ecclesiastic faction, the Radio Maryja movement, led by Father Rydzyk, a business-minded priest who runs a socially and politically influential broadcasting network. In 1991, Rydzyk founded the Radio Maryja Broadcast station based in Torun, followed by the Nasz Dziennik daily (founded in 1998) and the TV-station Trwam (founded in 2003). Besides its religious content, in the vein of traditionalist clericalism, Father Rydzyk and the Radio Maryja movement became a highly influential political force, endorsing several political parties and becoming an integral part of the reconstruction of the National Catholic political milieu (Krzeminski 2009, 2017). Relations with the church hierarchy remained ambiguous, despite several bishops voicing their approval of Rydzyk (Stanley 2016, p. 116). His political and social force results in that, despite clear ideological differences with the liberal and even the mainstream conservative faction, so far, only a minority among those openly opposed Rydzek (Tygodnik Powszechny 2018a).

The most prominent of the bishops of National Catholic persuasion are Bishop Edward Frankowski, the Archbishop of Kraków Marek Jędraszewski and Archbishop of Gdańsk Sławoj Leszek Głódź. Since the start of the asylum-political crisis, these prelates have "adapted the fear of Islam to the historically constructed notion of Poland as a bulwark of Christianity" (Pedziwiatr 2018).

In 2005, the coincidence of the death of Pope John Paul II with the first electoral victory of the PiS resulted in the increased influence of the National Catholic faction. Throughout his pontificate, Pope John Paul II was an omnipresent actor in the Polish Church and one whose heritage was claimed both by liberals and National Catholics. Nevertheless, and despite his conservatism in morality policies, Pope John Paul was critical of nationalism and rejected anti-Semitism. The Smolensk plane crash in November 2010, which killed President Lech Kaszynski and 99 other high Polish officials, was also a significant context for the mobilization of National Catholicism. Portrayed as a martyrdom for the nation, it served the dissemination of this political theology. 
4.1.4. Increasing Radicalization of the Church under the Second PiS Government (2015-2019)

The tradition of National Catholicism has a long pedigree in Poland, but never has it been so in line with a government in the post-World War II as during the second PiS government. In addition, according to studies on the ideological attitudes of the clergy, the new generation of priests is more nationalist than the previous one, with over $80 \%$ of the younger priests declaring their allegiance to National Catholic ideas (Peedziwiatr 2018, p. 471).

The PiS adoption of National Catholicism was gradual and tempered by pragmatism (Hall 2017). Founded in 2001, the party initially took a neutral stance regarding religion but progressively adopted the themes of National Catholicism. In 2004, it proposed the revision of the 1997 Constitution to grant the Church more privileges, including the adoption of a preamble with an Invocatio Dei, long claimed by the national Catholics. The party issued, in 2005, a document entitled "A Catholic Poland in a Christian Europe", committing to religious values and the defense of Poland's Catholic identity. Catholic values should determine the party's activities in all dimensions (Stanley 2016, p. 119). After the 2007 elections, the PiS could strengthen its position as it replaced the Catholic LPR and the left-the populist Self-defense (Samoobrona) as the representative of the economically disenfranchised and of the religious traditionalists (Stanley 2016, p. 111).

In the 2014 party program and during the 2015 election campaign, along with its apparently secular and nationalist outlook - the party pledged support for large Polish families, the renationalizing of capital, the media and the interpretation of Polish history. The PiS program contains several sections translating the teaching of the Catholic Church as a central element of Polish tradition, patriotism and political identity. The program portrays the Church, and its moral teachings, as the most relevant and undisputed moral voice. "We want to keep the specific status of the Catholic Church within our national state life" and to defend it "against unjust attacks". The program was silent about migration, Islam or asylum, but it emphasized Christianity as a basic historical and cultural experience and a core element of the universal value system (PiS 2014, p. 10). The Radio Maryja and related media outlets supported the PiS government, helping it to advance a religiously based national ideology (Gazeta Wyborcza 2015). The PiS, in turn, subsidizes the network, and cabinet ministers often appear on Radio Maryja's programs (Narkowicz 2018, p. 362).

The victory of the PiS in the 2015 general and presidential elections facilitated the Church's access to political power beyond the already established structures for churchstate cooperation. Previously, no church party existed (Grzymala-Busse 2015). The PiS government opened an opportunity for the most radical voices within the Church to express their attitudes and granted them access to the policy arena. In exchange, the PiS borrowed the Catholic identity as a legitimation of its illiberal and anti-democratic policies (Narkowicz 2018, p. 365). The government framed the refugees as an "invasion" threatening Poland, feeding the terrorist networks operating in Europe, and made extensive use of the "crisis as narrative device" (Fomina and Kucharczyk 2018). In addition, the PiS not only refused to take refugees (Narkowicz 2018, p. 366), but it also dismantled state services that supported ethnic and religious minorities and stopped support for NGOs helping refugees. The nationalist wing of the Catholic Church followed the government's anti-refugee stance (Stanley 2016, p. 119).

The rise of the Institute for Legal Culture Ordo Iuris exemplifies the heightened relevance of the illiberal nationalist camp. Founded in 2012 and funded by the PiS, the Ordo Iuris gained prominence in 2015, eventually authoring the draconian draft law on abortion pushed on the Parliament by the civic committee "Stop Abortion" (Marczewski 2018; Forsal 2016). Strongly linked with the Piotr Skarga Foundation, Ordo Juris is part of the Tradition Family Property, a global organization with roots in Brazil that promotes the adoption of restrictive morality legislation (Gazeta Wyborcza 2017).

The National Catholic Bishops heightened influence was displayed in November 2016, with the Independence Rally preceded, for the first time, by an official Mass in one of 
Warsaw's main parishes and celebratory Independence Day Masses being held all over Poland. This showed that "Polish nationalism had strong, if unofficial, support from conservatives in the Polish Catholic Church" (Catholic World Report 2016). The sermon recalled Poland's role in saving Western Europe from Islamic invasion in the 16th-century (Catholic World Report 2016).

The heightened National Catholics also reflected in the appointment, in December, of a prominent National Catholic prelate, Bishop Marek Jędraszewski, to the Archdiocese of Krakow. Krakow is the second most important diocese in the country and one traditionally headed by a liberal prelate, the most famous of which was Karol Wojtyla. Jędraszewski's selection showed the muscle of the anti-Islam discourse defending a Catholic Poland. It also illustrated the weak influence of Pope Francis in this process. Despite his ostensive opposition to the National Catholic faction, Pope Francis abstained from vetoing the appointment of its leader for this prominent seat. Pope Francis' compulsion to sign off Jedraszewski's appointment shows the multilayered and two-way relation between national Episcopates and the Vatican. The synthesis of Catholic nationalism exposed in the sermon of his inauguration mass was clear. Addressing Jesus Christ, Jędraszewski stated: "We, Poles, stand before you, together with our spiritual and temporal rulers, to recognize your rule. To surrender to your right and to entrust to you our country and the nation" (Deutschlandfunk 2017c).

With Arch. Jedraszewski as its informal leader, the National Catholic faction multiplied new events aimed at mobilizing the Catholics through nationalist slogans. In November 2017, the Solo Dios Basta foundation organized a 'Rosary at the Borders', a mass prayer to defend Poland from an Islamic invasion (Agence France Press 2017). In the sermon of the event's morning mass, Jeedraszewski defended the public relevance of God in Poland "against forces pushing the Poles to privatize their belief". Prime Minister Beata Szydło sent her greetings to the event (ntv 2017), and the vice president of the Sejm, PiS member Joachim Brudzinski publicly participated, referring to how Jan Sobieski III stopped, by means of the cross and the rosary, the Muslim invasion close to Vienna (Neue Osnabrücker Zeitung 2017). Radio Maryja broadcasted the event (Radio Maryja 2017).

The national Catholic prelates were also more visibly involved in nationalist events, such as rallies and public demonstrations. A case in point is the annual rally commemorating the Polish Independence of 1918. From 2015, counting with the support of the government and the Church, the Independence Day rallies gained immense relevance and attendance, becoming one of the meeting points of the European extreme right. By 2018, it was a massive nationalist and racist demonstration, reaching 250,000 participants. In 2016, the PiS government authorized the rally to traverse the main streets of Warsaw.

In 2015 and 2016, the church hierarchy allowed the celebration of official masses for Independence Day-and these were held in Warsaw's most prominent churches (Catholic World Report 2015). In 2017, the association of a nationalist agenda with a Christian identity was displayed in the rally's slogan, "We want God!" National Catholicism once again marched through the main streets of Warsaw, completing the process of fusion of Catholic symbols to back a radical form of nationalism sanctioned by the government (Gadek 2017).

The slogan of the Independence Day Rally in November 2019 was a clenched fist with a rosary around the fingers, with a hanging cross. The slogan "Bless the whole nation" (Miej w opiece naród caly) originated from a popular religious song to Mary of Częstochowa (Kadras 2019). In response to the accusations of church silence towards an abusive appropriation, the Bishops Conference spokesperson Pawel Rytel-Andrianik stated, "The rosary prayer is for everyone, for different cultures and nations and promotes to follow the way of life endorsed by the Gospel. Let us pray for peace in the world, also in the name of our fatherland" (Ekai 2019).

In summary, the section shows that, during the PiS government, the National Catholic faction of the Church radicalized their position and gained influence due to increased government support. The PiS ideological alignment with National Catholicism was used to legitimize the government's positions during the refugee and democracy crisis. Mainstream 
conservatives, seeing the deepening divide and the declining standing of the Church, resorted to distance from the government as it strayed too far from Catholic political theology. Although we focused here on the clerical level, we recognize that the polarization of these ideological divisions cut across all levels of the Church, from the ecclesiastic elite to the Catholic organizations and priests in local communities. It is particularly noticeable a wide and growing generation gap, where only $16 \%$ of adults under 40 declare that religion is important to them, against $40 \%$ of older people that state that view (Pew Research Forum 2018; CBOS 2020; Koschalka 2020).

\subsection{Papal Intervention}

In the summer of 2015, two years into his papacy, Pope Francis launched a campaign against the rejection of refugees by Europeans through pointed interventions against nationalism and xenophobia (Washington Post 2016). The defense of refugee rights in Europe-in line with the Catholic doctrine on refugees-was initially directed to Catholics and non-Catholics (Luxmoore 2017). In January 2016, Pope Francis started a campaign to discipline Catholic anti-immigration positions. Poland's Catholic Church-in alliance with a government that refused to grant Muslim migrants the status of asylum seekers (Kucharczyk and Mesežnikov 2019), was a glaring case. The Vatican addressed the Polish bishops, demanding a report on the church policies towards refugees (Report by the Polish Bishops Conference 2016). Later, the Pope visited Poland (26-31 July 2016) in a moment of high public and political polarization about the arrival of roughly two million migrants, mainly from the Middle East, and a wave of Islamic-backed terrorist attacks in Europe.

Pope Francis's sermon at Krakow's Wawel Church, in celebration of the World Youth Day, focused on defending the human rights of refugees and insisting on the duty of the Church to respect those rights. Francis stated that the Church needs a "spirit of readiness to welcome those fleeing from wars and hunger, and solidarity with those deprived of their fundamental rights" (Luxmoore 2017). In the sermon of the farewell mass to Poland, Pope Francis' message was that Islam is not intrinsically violent (RP-online 2016).

Pope Francis did not intervene in the democracy crisis. Nevertheless, the Polish Episcopate followed the pro-democratic doctrine instituted in the pontificates of Pope John Paul II (1978-2004) and sustained by Pope Benedikt XVI (2004-2013). While the Polish bishops tried to defend democratic institutions, especially the rule of law, they maintained a strict conservatism in their conservative approach to moral issues. Support for democracy was the glue between the conservative and liberal tendencies in the Church during these pontificates, and together with a conservative stance on moral issues, it allowed for the subduing of the conflict between the liberal and conservative factions (Wright-Carozza and Philpott 2012; Perreau-Saussine 2012).

Pope Francis' initiatives of liberalization towards several issues of moral doctrine (communion for divorced Catholics, doctrine regarding homosexuality, the prohibition of contraception) upended the truce between the liberals and the conservative wing. Conservatives reacted against the program of Pope Francis, resulting in increased tensions with the remaining factions. In addition, Francis's questioning of the capitalist system destabilized the liberals, further heightening internal conflicts.

Pope Francis' intervention against the cooperation of the Polish Church with the government's refugee policy was a factor driving a wedge between Catholic nationalism and the rest of the Church in Poland. Francis emboldened the liberal resistance against the government refugee policies and obliged the mainstream conservatives to take a stance regarding the government's refusal to admit refugees while strengthening the internal tensions within the Church.

\section{Analysis}

The article confirms Grzymala-Busse's (2015) insight that the alliances of Christian churches with political parties are costly and of Philpott's statement of the impact of the Vatican Council II liberal theology. Poland's high religiosity and relative insulation from 
the trends of secularization in the second half of the 20th-century makes this analysis a hard case of these two theories. The analysis shows that the hierarchy of the Church (national and transnational), assessing the high costs of this alliance, responded to the authoritarian turn of the government by asserting its distance from it and reinstating the Catholic support for a version of liberal democracy. The analysis shows evidence of the independent effects of both elements.

First, the Episcopate strategy of disentanglement of Catholicism from nationalism appears strongly related to the rising costs of the alliance with the PiS. A part of these costs, which we did not explore directly in the article, is the growing disenfranchisement of the liberal laity. Facing an increasingly polarized church, the Episcopal Conference tried to undercut the empowered and radicalized National Catholic faction. Signs of this are, from 2017, the growing distance towards the increasingly radical Independence Day celebrations, the condemnation of nationalism as un-Christian and an elicited criticism of the refugee policies of the government. Moreover, the Episcopate's direct interventions for President Duda to veto the judicial reforms were a response to the government's efforts at undermining the separation of powers through the limitation of the independence of the judiciary. The Episcopate was equally forceful when the government attempted to tamper with the electoral laws and, as President Duda tried to rewrite the constitution, the Episcopate leader laid out the terms of the Catholic support to liberal democracy.

Second, although the analysis shows the relevance of the transnational pro-democratic theology in driving the actions of the church authorities (Philpott's proposition), it also demonstrates the relatively limited impact of Pope Francis in the process. Pope Francis's direct intervention during the asylum political crisis helps to explain the timing of the Episcopate's turn. After the Pope's visit to Poland in July 2016, the Episcopate voiced for the first time its disagreement with the government's refugee policy. However, Pope Francis had no impact during the democracy crisis and signed off the appointment of a prominent National Catholic prelate, Marek Jędraszewski, as Archbishop of Kraków. The article also shows the increasing tensions between the Catholic conception of liberal democracy, which demands a reserve from majoritarianism for certain moral issues, and an increasingly accepted trend in Western democracies to recognize issues such as abortion and gay rights as human rights. These were a factor facilitating the complicity between the Episcopate and the PiS in the run-up to the 2015 elections.

After portraying the growing Catholic support for nationalism and the alliance that eventually the Polish Episcopate concluded with the PiS, we analyze the impact of this alliance for the church authorities, especially the Episcopate and the clergy. As a wider contribution, the article showcases how challenging the association with nationalism is for the ecclesiastic and ideological structures of the Church, especially under the current crisis of liberal democracy. As a concluding note, we venture to observe that the deepening rifts between liberals, conservatives and nationalists also are increasingly observable among the Catholic electorate. A case in point is the steep decline in support for PiS after the almost total ban on abortion by the Constitutional Court in November 2020.

Author Contributions: Conceptualization, M.M.R. and A.H.; methodology, M.M.R. and A.H.; investigation, M.M.R. and A.H.; writing-original draft preparation, M.M.R. and A.H.; writing—review and editing, M.M.R.; All authors have read and agreed to the published version of the manuscript.

Funding: This research received funding from Fundação para a Ciência e Tecnologia, Ministério da Ciência,Tecnologia e Ensino Superior de Portugal, Projeto Plurianual UIDB/04627/2020.

Conflicts of Interest: The authors declare no conflict of interest.

\section{References}

Acherson, Neal. 1981. The Polish August: The Self-Limiting Revolution. London: Penguin.

Agence France Press. 2017. Polish Catholics Come Together at the Country's Borders, Praying to 'Save Poland.'. Public Radio International. July 10. Available online: https://www.pri.org/stories/2017-10-07/polish-catholics-come-together-countrysborders-praying-save-poland (accessed on 20 October 2020). 
Anderson, John. 2007. The Catholic Contribution to Democratization's 'Third Wave': Altruism, Hegemony or Self-Interest? Cambridge Review of International Affairs 20: 383-99. [CrossRef]

Catholic, Herald. 2017. Polish Bishops Criticise Government over Migrants. Catholic Herald, September 18.

Catholic World Report. 2015. The Priest Who Is the New Face of Polish Nationalism. December 10. Available online: http:/ / www. catholicworldreport.com/2015/12/10/the-priest-who-is-the-new-face-of-polish-nationalism/ (accessed on 12 November 2020).

Catholic World Report. 2016. Polish Independence Day Marches Demonstrate Ideological Divides. November 16. Available online: http: //www.catholicworldreport.com/2016/11/16/polish-independence-day-marches-demonstrate-ideological-divides / (accessed on 12 November 2020).

CBOS. 2020. Religijność Polaków w Ostatnich 20 Latach. CBOS Komunikat z Badan Nr 63/2020. Warsaw: CBOS, Available online: https:/ / cbos.pl/SPISKOM.POL/2020/K_063_20.PDF (accessed on 15 December 2020).

Christians, Louis-Léon. 2006. Religious Law and Secular Law in Democracy: The Evolutions of the Roman Catholic Doctrine after the Second Vatican Council. BYU L. Rev. 2006: 661.

Crux. 2018. Polish Archbishop Condemns Government Stance on Refugees. Crux. March 23. Available online: https:/ / cruxnow.com/ global-church/2018/03/polish-archbishop-condemns-government-stance-on-refugees/ (accessed on 2 October 2020).

Declaration on Religious Freedom. 1965. Dignitatis Humanae, On the Right of the Person and of Communities to Social and Civil Freedom in Matters Religious, Promulgated by His Holiness Pope Paul VI. Available online: https://www.vatican.va/archive/ hist_councils/ii_vatican_council/documents/vat-ii_decl_19651207_dignitatis-humanae_en.html (accessed on 14 January 2020).

Deutsche Welle. 2017. How the Catholic Church Ties in to Poland's Judicial Reform. Deutsche Welle. July 24. Available online: https: / / www.dw.com/en/how-the-catholic-church-ties-in-to-polands-judicial-reform/a-39809383 (accessed on 12 November 2020).

Deutschlandfunk. 2017a. Katholische Kirche in Polen-Nah am Staat, weit weg vom Papst (Catholic Church in Poland-Close from State, Far away from the Pope). January 30. Available online: https:/ / www.deutschlandfunk.de/katholische-kirche-in-polennah-am-staat-weit-weg-vom-papst.886.de.html?dram:article_id=377637 (accessed on 12 November 2020).

Deutschlandfunk. 2017b. Polnische Bischofskonferenz-Patriotismus ja, Nationalismus Nein. April 5. Available online: https:/ /www. deutschlandfunk.de/polnische-bischofskonferenz-patriotismus-ja-nationalismus.886.de.html?dram:article_id=385226 (accessed on 12 November 2020).

Deutschlandfunk. 2017c. Rosenkranz-Beten an den Landesgrenzen. October 9. Available online: https:/ /www.deutschlandfunk.de/ polen-rosenkranz-beten-an-den-landesgrenzen.1773.de.html?dram:article_id=397736 (accessed on 12 November 2020).

Deutschlandfunk. 2017d. Polens Katholiken-Kirche auf Distanz zur Regierung. September 7. Available online: https://www. deutschlandfunk.de/polens-katholiken-kirche-auf-distanz-zur-regierung.886.de.html?dram:article_id=395150 (accessed on 12 November 2020).

Ekai. 2019. Rzecznik Episkopatu Komentuje logo Marszu Niepodległości. October 22. Available online: https://ekai.pl/rzecznikepiskopatu-komentuje-logo-marszu-niepodleglosci/ (accessed on 15 December 2020).

Evangelisch. 2017. Polen und die 'Parteiische Kirche' (Poland and the Partisan Church). November 24. Available online: https: / / www.evangelisch.de/inhalte/147117/24-11-2017/polen-und-die-parteiische-kirche (accessed on 2 October 2020).

Fomina, Joanna, and Jacek Kucharczyk. 2018. From politics of fear to securitization policies? Poland in the face of migration crisis. In Phantom Menace. The Politics and Policies of Migration in Central Europe. Edited by Jacek Kucharczyk and Grigorij Mesežnikov. Prague: Heinrich-Boell Stiftung, Institute for Public Affairs, pp. 185-202.

Forsal. 2016. Wszyscy Ludzie Ordo Iuris. Kto Jest Kim w Konserwatywnym Think Tanku? October 15. Available online: https:/ /forsal. pl/artykuly/984518,wszyscy-ludzie-ordo-iuris-kto-jest-kim-w-konserwatywnym-think-tanku.html (accessed on 15 February 2020).

Gądecki, Stanislaw. 2018. Homilia. Demokracja. Uroczystość św. Stanisława, Biskupa i Męczennika, Głównego Patrona Polski (Sermon: Democracy, Celebration of St. Stanislaw, Bishop and Martyr, Main Patron of Poland). Polish Bishops Conference. Available online: https:/ / episkopat.pl/homilia-demokracja-uroczystosc-sw-stanislawa-biskupa-i-meczennika-glownego-patrona-polskikrakow-skalka-13-05-2018/ (accessed on 15 October 2020).

Gadek, Jacek. 2017. Marsz Niepodległości 2017 Jest Inny niż Poprzednie. Odpowiadamy, Dlaczego (The Independence March of 2017 is Different from the Preceding Ones. We Explain Why). Gazeta Wyborcza. October 11. Available online: https://wiadomosci. gazeta.pl/wiadomosci/7,114871,22623393,marsz-niepodleglosci-2017-jest-inny-niz-poprzednie-odpowiadamy.html (accessed on 20 January 2020).

Garbowski, Christopher. 2014. Religious Life in Poland: History, Diversity and Modern Issues. Jefferson: McFarland \& Company.

Gazeta Wyborcza. 2015. Radio Maryja ma Nowego Wroga. Teraz Straszy Islamizacją. December 5. Available online: https: / / wyborcza.pl/1,75398,19297456,radio-maryja-ma-nowego-wroga-teraz-straszy-islamizacja.html (accessed on 15 August 2020).

Gazeta Wyborcza. 2017. Ordo Iuris, Sekta z Brazylii i... Dygnitarze Putina. April 7. Available online: http://wyborcza.pl/7,75968,2160 5548,ordo-iuris-sekta-z-brazylii-i-dygnitarze-putina.html (accessed on 15 May 2020).

Gazeta Wyborcza. 2019. Organizatorzy Marszu Niepodległości Chcieli Mszy, ale Kuria się nie Zgodziła. Więc Poszli do Wyklętych Lefebrystów. November 9. Available online: https: / / wyborcza.pl/magazyn/7,124059,25392371,organizatorzy-marszuniepodleglosci-chcieli-mszy-ale-kuria.html (accessed on 15 June 2020).

Gowin, Jarosław. 1999. Kościoł w Czasach Wolności 1989-1999 [Die Kirche in Zeiten der Freiheit 1989-1999]. Krakow: Wydawnictwo ZNAK. 
Grabowska, Mirosława. 2017. Religiosity, the Catholic Church, and Politics in Poland. In Religion, Politics, and Values in Poland. Edited by Sabrina P. Ramet and Irena Borowik. London: Palgrave Macmillan, pp. 257-88.

Gregg, Samuel. 2002. Challenging the Modern World: Karol Wojtyla/John Paul II and the Development of Catholic Social Teaching. Lanham: Lexington Books.

Grzymala-Busse, Anna Maria. 2015. Nations under God: How Churches Use Moral Authority to Influence Policy. Princeton: University Press.

Hall, Aleksander. 2017. Kościoł Wobes Panstwa PiS. Wiez, July.

Hennig, Anja, and Mirjam Weiberg-Salzmann. 2020. Religion and Illiberal Politics in Europe and Beyond. Concepts, Actors and Identity Narratives. Frankfurt and New York: Campus.

John Paul II. 1999. Address to the Polish Parliament. Warsaw. June 11. Available online: http://www.vatican.va/holy_father/john_ paul_ii/travels/documents/hf_jp-ii_spe_11061999_warsaw-parliament_en.html (accessed on 2 October 2020).

Kadras, Dominika. 2019. Boże, miej w opiece Marsz Niepodległośc. HOLISTIC.news. November 12. Available online: https: / / holistic.news/boze-miej-w-opiece-marsz-niepodleglosci/ (accessed on 30 October 2020).

Koschalka, Ben. 2020. Most Poles Religious but Few 'Strongly Committed' to Their Faith, New Data Show. Notes From Poland. March 12. Available online: https:/ / notesfrompoland.com/2020/03/12/most-poles-are-religious-but-few-are-strongly-committedto-their-faith-show-new-data/ (accessed on 20 January 2020).

Krzeminski, Ireneusz. 2009. Czego Nas Uczy Radio Maryja? In Socjologia Tresci i Recepcji Rozglosni, Wydawnictwo Wydawnictwa Akademickie i Profesjonalne. Warsaw: WAiP.

Krzeminski. 2017. Radio Maryja and Fr. Rydzyk as a Creator of the National-Catholic Ideology. In Religion, Politics, and Values in Poland. Palgrave Studies in Religion, Politics, and Policy. Edited by Sabrina P. Ramet and Irina Borowik. New York: Palgrave MacMillan.

Kucharczyk, Jacek, and Grigorij Mesežnikov, eds. 2019. Phantom Menace. The Politics and Policies of Migration in Central Europe. Bratislava: Henrich-Boll Stiftung Prague, Available online: https://cz.boell.org/en/2019/02/14/phantom-menace (accessed on 14 October 2020).

Künkler, Mirjam, and Julia Leininger. 2021. (forthcoming). Democratization and Democratic Backsliding: When Does Religion Matter? Ann Arbor: University of Michigan Press.

Linz, Juan J. 1991. Church and State in Spain from the Civil War to the Return of Democracy. Daedalus 120: 159-78.

Luxmoore, Jonathan. 2017. Eastern Europe's Church Leaders Face Growing Criticism over Refugees. National Catholic Reporter. September 3. Available online: https:/ / www.ncronline.org/news/world/eastern-europes-church-leaders-face-growing-criticism-overrefugees (accessed on 30 October 2020).

Manent, Aline-Florence. 2018. Democracy and Religion in the Political and Legal Thought of Ernst-Wolfgang Böckenförde. Oxford Journal of Law and Religion 7: 74-96. [CrossRef]

Marczewski, Paweł. 2018. Freedom to Exclude: Conservative CSOs in Law and Justice Poland-The Mobilization of Conservative Civil Society. Carnegie Europe. April 10. Available online: https:/ / carnegieeurope.eu/2018/10/04/freedom-to-exclude-conservativecsos-in-law-and-justice-poland-pub-77377 (accessed on 18 November 2020).

Meyer Resende, Madalena. 2014. Catholicism and Nationalism. Changing Nature of Party Politics. London and New York: Routledge. [CrossRef]

Meyer Resende, Madalena. 2018. A Holy Alliance between the Catholic Church and Constitution-Makers? The Diffusion of the Clause of Cooperation in Third Wave Democracies. Politics and Religion 11: 55-78. [CrossRef]

Minkenberg, Michael. 2018. Between Christian and Multicultural Democracy: Religious Legacies and Minority Politics. West European Politics 41: 53-79. [CrossRef]

Narkowicz, Kasia. 2018. 'Refugees Not Welcome Here': State, Church and Civil Society Responses to the Refugee Crisis in Poland. International Journal of Politics, Culture, and Society 31: 357-73. [CrossRef]

Neue Osnabrücker Zeitung. 2017. Aktion in Polen: Mit Rosenkränzen an die Grenzen. October 8. Available online: https://http: //www.noz.de/deutschland-welt/politik/artikel/962429/aktion-in-polen-mit-rosenkraenzen-an-die-grenzen (accessed on 30 October 2020).

Nosowski, Zbigniew. 2016. Ein Neues Bündnis Zwischen Thron und Altar? Der Polnische Katholizismus und die Versuchung der Politisierung. Ost-West Europäische Perspektiven OWEP. Available online: https:/ / www.owep.de/artikel/1010-neues-buendniszwischen-thron-und-altar (accessed on 18 November 2020).

ntv. 2017. Rosenkränze an den Grenzen. Zehntausende Beten für “Rettung Polens. October 8. Available online: http:/ /www.n-tv.de/ politik/Zehntausende-beten-fuer-Rettung-Polens-article20071987.html (accessed on 30 October 2020).

OKO Press. 2018. Marsz Niepodległości 2018: Wygrali Nacjonaliści, Przegrał PiS i Rzeczypospolita. November 11. Available online: https:/ / oko.press/marsz-niepodleglosci-2018-wygrali-nacjonalisci-przegral-pis-i-rzeczypospolita/ (accessed on 17 October 2020).

Pankowski, Rafal. 2018. The Internationalisation of Nationalism and the Mainstreaming of Hate-The Rise of the Far Right in Poland. In Integration, Disintegration, Nationalism: Yearbook 2018. Edited by Eric Canepa and Walter Baier. London: Merlin Press, Available online: http:/ / www.transform-network.net/de/publications/jahrbuch/overview/article/yearbook-2018/theinternationalisation-of-nationalism-and-the-mainstreaming-of-hate-the-rise-of-the-far-right-in/ (accessed on 30 October 2020). 
PAP. 2014. Polish Bishops Elect New Leader 'at Delicate Time.'. Polskie Radio dla Zagranicy. March 13. Available online: http: / / archiwum.thenews.pl/1/9/Artykul/165024,Polish-bishops-elect-new-leader-at-delicate-time (accessed on 18 November 2020).

Pastoral Constitution on the Church in the Modern World. 1965. Gaudium et Spes (The Joy and the Hope). Available online: https://www.vatican.va/archive/hist_councils/ii_vatican_council/documents/vat-ii_const_19651207_gaudium-et-spes_ en.html (accessed on 15 August 2016).

Pędziwiatr, Konrad. 2018. The Catholic Church in Poland on Muslims and Islam. Patterns of Prejudice 52: 461-78. [CrossRef]

Perreau-Saussine, Emile. 2012. Catholicism and Democracy: An Essay in the History of Political Thought. Princeton: Princeton University Press.

Pew Research Center. 2017a. In EU, There's an East-West Divide over Religious Minorities, Gay Marriage, National Identity. Pew Research Center. Available online: https:/ / www.pewresearch.org/fact-tank/2018/10/29/east-west-divide-within-the-eu-onissues-including-minorities-gay-marriage-and-national-identity / (accessed on 2 October 2020).

Pew Research Center. 2017b. Religion a Part of National Identity in Central, Eastern Europe. Pew Research Center. Available online: https: / www.pewresearch.org/fact-tank/2017/11/03/many-central-and-eastern-europeans-see-link-between-religionand-national-identity / (accessed on 2 October 2020).

Pew Research Forum. 2018. Young Adults around the World Are Less Religious. Pew Research Center's Religion E Public Life Project. June 13. Available online: https:/ / www.pewforum.org/2018/06/13/young-adults-around-the-world-are-less-religious-byseveral-measures / (accessed on 2 October 2020).

Philpott, Daniel. 2004. The Catholic Wave. Journal of Democracy 15: 32-46. [CrossRef]

PiS. 2014. Zdrowie, Praca, Rodzina: Program Prawa i Sprawiedliwości. Available online: http://pis.org.pl/dokumenty?page=2 (accessed on 30 October 2020).

Polish Bishops Conference. 2016. The Church in Poland: Welcoming Refugees. A Report by the Polish Episcopal Conference to the Holy See. Vatican. July 23. Available online: https://press.vatican.va/content/salastampa/en/bollettino/pubblico/2016/07/23 /160723a.html (accessed on 30 October 2020).

Polish Bishops Conference. 2017. Chrześcijański Kształt Patriotyzmu (The Christian Shape of Patriotism). Available online: https: / / episkopat.pl/chrzescijanski-ksztalt-patriotyzmu-dokument-konferencji-episkopatu-polski-przygotowany-przezrade-ds-spolecznych/ (accessed on 14 October 2020).

Polish Bishops Conference. 2018. Przewodniczący Episkopatu: Zdrowa Demokracja Jest Oparta na Wartościach, na Prawie Moralnym (Leader of the Episcopate: The Health of Democracy is Dependent on Values and Moral Laws). Available online: https: / / episkopat.pl/przewodniczacy-episkopatu-zdrowa-demokracja-jest-oparta-na-wartosciach-na-prawie-moralnym/ (accessed on 30 October 2020).

Pontifical C Pontifical Council Cor et Unum. 2013. Welcoming Christ in Refugees and Forcibly Displaced Persons: Pastoral Guidelines; Vatican City. Available online: http://www.vatican.va/roman_curia/pontifical_councils/corunum/corunum_en/pubblicazioni_en/ rc_pc_corunum_doc_20130606_refugees_2013_presentazione_en.html (accessed on 14 October 2020).

Pontifical Council for Justice and Peace. 2005. Compendium of the Social Doctrine of the Church. Available online: http:/ /www.vatican. va/roman_curia/pontifical_councils/justpeace/documents/rc_pc_justpeace_doc_20060526_compendio-dott-soc_en.html (accessed on 14 October 2020).

Pope Benedict XVI. 2010. Message for the 97th World Day of Migrants and Refugees. Available online: http:/ / w2.vatican.va/content/ benedict-xvi/en/messages/migration/documents/hf_ben-xvi_mes_20100927_world-migrants-day.html (accessed on 14 October 2020).

Radio Maryja. 2017. Ogromny Sukces "Różańca do Granic”. October 9. Available online: http://www.radiomaryja.pl/kosciol/ ogromny-sukces-rozanca-granic/ (accessed on 30 October 2020).

Redakcja Więz. 2018. Bp Zadarko: Nieprzestrzeganie konstytucji jest obrazą Boga (Bishop Zadarko: Failure to comply with the constitution is an offense against God). Więź. March 5. Available online: http://wiez.com.pl/2018/05/04/bp-zadarkonieprzestrzeganie-konstytucji-jest-obraza-boga/ (accessed on 8 November 2020).

RP-online. 2016. Weltjugendtag in Krakau: Papst Predigt Gegen Hass und Für Neue Menschlichkeit. July 30. Available online: https://rp-online.de/panorama/ausland/weltjugendtag-in-krakau-papst-predigt-gegen-hass-und-fuer-neuemenschlichkeit_aid-18161083 (accessed on 18 November 2020).

Stanley, Ben. 2016. Defenders of the Cross: Populist Politics and Religion in Post-Communist Poland. In Saving the People: How Populists Hijack Religion. Edited by Duncan McDonnell, Nadia Marzouki and Olivier Roy. London: C. Hurst \& Co, Ltd., pp. 109-28.

Stein, Tine. 2018. The Böckenförde Dictum-On the Topicality of a Liberal Formula. Oxford Journal of Law and Religion 7: 97-108. [CrossRef]

Stepan, Alfred C. 2000. Religion, Democracy, and the "Twin Tolerations". Journal of Democracy 11: 37-57. [CrossRef]

Turska-Kawa, Agnieszka, and Waldemar Wojtasik. 2017. Diversity of Roman Catholics in Poland and Their Socio-Institutional Preferences. Religio 25: 43-86.

Tygodnik Powszechny. 2018a. Oskarżam. January 15. Available online: http://www.tygodnikpowszechny.pl/oskarzam-151647 (accessed on 8 November 2020).

Tygodnik Powszechny. 2018b. Po artykule “Oskarżam”: Odpowiadamy Rzecznikowi Episkopatu. January 20. Available online: https:/ / www.tygodnikpowszechny.pl/comment/20191 (accessed on 8 November 2020). 
Vatican News. 2018. Polnischer Bischof verteidigt Flüchtlingskurs der Kirche (Polish Bishop Defends the Refugee Policy of the Church). March 17. Available online: https:/ / www.vaticannews.va/de/kirche/news/2018-03/oesterreich-polen-kirche-fluechtlingepolitik-zadarko.html (accessed on 18 November 2020).

Walicki, Andrzej. 1994. Philosophy and Romantic Nationalism: The Case of Poland. Notre Dame: University of Notre Dame.

Walicki. 2000. The Troubling Legacy of Roman Dmowski. East European Politics and Societies 14: 12-46.

Washington Post. 2016. How Pope Francis Is Leading the Catholic Church against Anti-Migrant Populism. June 3. Available online: www.washingtonpost.com\%2fworld\%2feurope $\% 2$ fhow-pope-francis-is-leading-the-catholic-church-against-anti-migrantpopulism\%2f2017\%2f04\%2f10\%2fd3ca5832-1966-11e7-8598-9a99da559f9e_story.html (accessed on 18 November 2020).

Weigel, George. 2010. The End and the Beginning: Pope John Paul II-The Victory of Freedom, the Last Years, the Legacy. New York: Image Books.

Williams, George. 1981. The Mind of John Paul II: Origins of His Thoughts and Actions. New York: Seabury Press.

Wright-Carozza, Paolo, and Daniel Philpott. 2012. The Catholic Church, Human Rights, and Democracy: Convergence and Conflict with the Modern State. Logos: A Journal of Catholic Thought and Culture 15: 15-43. [CrossRef]

Zubrzycki, Geneviève. 2006. The Crosses of Auschwitz. Nationalism and Religion in Post-Communist Poland. Chicago: The University of Chicago Press.

Żuk, Piotr, and Pawel Żuk. 2019. Dangerous Liaisons between the Catholic Church and State: The Religious and Political Alliance of the Nationalist Right with the Conservative Church in Poland. Journal of Contemporary Central and Eastern Europe 27: 191-212. [CrossRef]

Żuk, Piotr, and Paweł Żuk. 2020. 'Murderers of the Unborn' and 'Sexual Degenerates': Analysis of the 'Anti-Gender' Discourse of the Catholic Church and the Nationalist Right in Poland. Critical Discourse Studies 17: 566-88. [CrossRef] 